\title{
Production of Urban Space and the occurrence of malaria in the Brazilian Amazon: the Porto Velho case
}

\author{
Produção do Espaço Urbano e ocorrência da malária \\ na Amazônia Brasileira: o caso Porto Velho
}

Renata Duarte Marques (https://orcid.org/0000-0001-6168-3827) ${ }^{1}$

Jussara Rafael Angelo (https://orcid.org/0000-0003-2324-1053) ${ }^{1}$

Alzemar Alves de Lima (https://orcid.org/0000-0003-0496-4387) ${ }^{2}$

Trevon Fuller (https://orcid.org/0000-0001-9954-4267) ${ }^{3}$

Christovam Barcellos (https://orcid.org/0000-0002-1161-2753) ${ }^{4}$

${ }^{1}$ Escola Nacional de Saúde Pública Sérgio Arouca, Fundação Oswaldo Cruz (Fiocruz). R. Leopoldo Bulhões 1480, Manguinhos. 21041-210 Rio de Janeiro RJ Brasil.

duarterenatam@gmail.com ${ }^{2}$ Centro de Pesquisa em Medicina Tropical de Rondônia, Laboratório de Epidemiologia. Porto Velho RO Brasil.

${ }^{3}$ Institute of the Environment and Sustainability, University of California. Los Angeles California USA.

${ }^{4}$ Departamento de Informação em Saúde, Fiocruz. Rio de Janeiro RJ Brasil.

\begin{abstract}
Due to intense ongoing urbanization in the Amazon, the urban pattern of malaria may be changing, both in its spatial distribution and epidemiological profile. The purpose of this paper is to analyze how the process of production of urban space in Porto Velho, the capital of the state of Rondonia, Brazil has contributed to the occurrence and maintenance of urban malaria. Using data collected from the Malaria Epidemiological Surveillance System (SIVEP-Malaria), we calculated malaria indices for the districts of Porto Velho from 2005 to 2018. We also developed two typologies for classifying urban space based on functional characteristics and features of the landscape. While the former considers characteristics of urban space in Porto Velho, the latter is based on suitability for malaria vectors. We found that the annual parasite index declined in Porto Velho during the study period. However, changes in the index were not uniform across the districts of the city. Periurban areas showed no decline in the index, which we attribute to these areas' high vegetation density and hydrological characteristics.

Key words Urban Malaria, Health Surveillance, Spatial Analysis, Porto Velho, Amazon
\end{abstract}

Resumo A Amazônia tem passado por um intenso processo de urbanização em anos recentes, produzindo transformações na organização espacial da região que podem estar refletindo no padrão espaço temporal da malária urbana. O objetivo deste trabalho é compreender como o processo de produção do espaço urbano do município de Porto Velho-RO, tem corroborado para a ocorrência e manutenção da malária urbana. Os dados levantados no Sistema de Vigilância Epidemiológica (SIVEP-Malária) possibilitaram o cálculo do Índice Parasitário Anual (IPA) de malária para os bairros da cidade de Porto Velho dos anos de 2005 a 2018 e a construção de duas tipologias da paisagem do espaço urbano. A primeira considerou o processo de produção do espaço urbano de Porto Velho; a segunda se baseou nas condições de receptividade para o vetor da malária. A ocorrência da malária em Porto Velho vem declinando de forma diferenciada ao longo do território, havendo uma tendência de permanência nas áreas periurbanas com maior densidade de vegetação e hidrografia. Palavras-chave Malária Urbana, Vigilância em Saúde, Análise Espacial, Porto Velho, Amazônia 


\section{Introduction}

The settlement of the Brazilian Amazon has followed a "boom and bust" economic pattern. During expansion periods, the economy has typically been highly specialized. Salient examples include epochs of intensive mineral extraction and specialization in the production of hydroelectric power. Such undertakings, coupled with rapid economic and population growth, have triggered migration and land use/land cover change. These processes, in turn, have had social and public health implications, such as influencing the size and location of malaria epidemics ${ }^{1-3}$.

Malaria remains a serious public health problem and is the cause of considerable morbidity and mortality. Fully $99.7 \%$ of Brazil's malaria cases occur in the Amazon region, with most cases concentrated in a small number of hotspot areas. Transmission in this region can be attributed to a variety of processes. Biological processes include the mosquito life cycle, while geographic ones encompass the dynamics of climate, hydrography, and vegetation. Among the ecological processes implicated in malaria transmission are deforestation and large infrastructure projects. Finally, there are social processes such as the presence of large populations living near forests and rivers in settlements without adequate housing, streets or sidewalks ${ }^{4-6}$. These processes act in concert to make the Amazon region particularly prone to malaria transmission.

Although the incidence of malaria is higher in rural areas, the past decade has seen a substantial increase in its incidence in urban spaces in Porto Velho. Differences in malaria in urban and rural areas can be attributed to factors such as urban microhabitats that favor the growth of Anopheles vectors and the behavior of human hosts in these habitats. Mosquito survival, reproduction, and development is linked to aspects of urban microclimate including temperature, vegetation, relative humidity, and rainfall. Among the drivers influencing human exposure to these vectors are insecticide spraying, public health surveillance programs, housing, and the movement of populations between urban and rural areas. Each of these drivers has the potential to influence the risk of malaria transmission ${ }^{7-10}$.

The municipality of Porto Velho, the capital of the state of Rondonia, is directly affected by these processes. Founded in 1907, the municipality has experienced cycles of deforestation and the construction of projects, roads and dams, which have altered social conditions and land use $^{11}$. Since 2000, Porto Velho has undergone a particularly dramatic transformation due to the construction of two hydroelectric power stations (HPS) along the Madeira River ${ }^{12}$.

According to Carlos $^{13}$, urban space can be thought of as constituting both a prerequisite for and a product of the process through which society reproduces itself. In this manner, a city can be viewed as being emblematic of the organization of a society. One of the side effects of the structure of a city is that social class places limits upon the quality of the services and living conditions to which an individual has access ${ }^{14}$. The production of urban space is the result of a variety of undertakings, many of which have conflicting objectives, and a diverse group of social actors, which have the capacity to exercise their influence from distant locations. A salient example of this process are highway and riverine transportation networks as well as the construction of hydroelectric power plants along the Madeira River. These infrastructure projects redefined Porto Velho's role in the region's economy, as well as creating new spaces in the city intended to provide housing both for low-income migrant workers and for the middle class.

These construction projects attracted workers from other states resulting in significant population growth and revitalization of the local economy, as evidenced by data from the National Household Survey of 2010 (Portuguese acronym: PNAD). The results indicated that at that time less than $10 \%$ of the population had lived in the municipality for more than a decade ${ }^{10}$. The objective of the present study is to assess the extent to which, if any, population recent growth and land use change have influenced the Annual Parasite Index (API) in Porto Velho.

\section{Methods}

\section{Study area}

The municipality of Porto Velho is located in the Amazon biome in northern Brazil. In addition to being Rondônia's most populous city, it is a particularly large municipality that covers fully $15 \%$ of the state.

The urban center of Porto Velho covers $122.57 \mathrm{~km}^{2}$ divided into 69 neighborhoods. In the present analysis, the urban center is defined as the neighborhoods located within the Greater Porto Velho Economic Zone listed in Municipal Law 311 of June 30, 2008. 
While the city expanded radially from the banks of the Madeira River, its growth was curtailed by physical conditions such as the presence of streams, or institutional conditions such as the airport to the north and a military base and Highway BR-364 to the south. In 2008, its territory was modified mainly as a result of the construction of two major projects, namely, the Santo Antônio and Jirau HPSs. These projects substantially modified the region, boosting the local economy and attracting thousands of temporary workers and residents to the municipality ${ }^{10,14,15}$.

\section{Study design}

This is an ecological, epidemiological study, consisting of spatial analysis of the urban area of Porto Velho, which aims to understand how the process of production of urban space in the municipality has been associated with the occurrence and persistence of malaria from 2005-2018. We also aimed to analyze the extent to which social and spatial processes contribute to malaria endemics.

Data were collected from the Ministry of Health's Epidemiological Surveillance Information System (SIVEP-Malária) for 2005-2018 to identify the dates and locations of malaria cases in the urban area of Porto Velho. Case data for the entire state of Rondônia and were analyzed using RStudio 1.0.153.

Regarding demographic data, data from the 2000 and 2010 Census and 2007 Population Count from the Brazilian Institute of Geography and Statistics (IBGE) were used. These data were employed to observe and quantify demographic trends as well as to calculate the API.

Environmental, social, and health data were processed using Terraview 4.2.0 Geoprocessing software developed by the National Institute for Space Research (INPE) and ArcMap 10.1 developed by Esri.

Field observations and qualitative document analysis were used to identify and characterize the process of construction of the urban space of Porto Velho and its current context in the context of the settlement of the Amazon. Gray literature from institutions such as the Porto Velho Mayor's Office and IBGE were consulted. We also surveyed papers and academic works that addressed the establishment and occupation of the territory, and important social and economic developments in recent years.

We developed two typologies to classify Porto Velho's neighborhoods into categories. The first was based on characteristics of urban spaces, and the second, on the malaria vector suitability conditions. Tauil et al. ${ }^{1}$ and Tauil ${ }^{16}$ define suitability as the presence of the vector in sufficient density to establish transmission or trigger epidemics in a region, through conditions that favor the presence and maintenance of the vector.

The variables from the 2010 Population Census "average monthly household income" and "percentage of population growth between 2007 and 2010" were utilized to create the classes of the typology of characteristics of urban spaces. Based on these variables the following classes were established: central area (high income and low growth); consolidated suburb (low income, low growth); suburb in expansion (low income, high growth); middle class area in expansion (medium income, high growth).

We hypothesized that the suitability of a neighborhood for mosquito breeding would depend upon the presence of vegetation and water bodies, because Anopheles darlingi requires deep, clean, and clear water sources that are either fully exposed to the sun or partially shaded by floating vegetation $^{17}$.

We created the typology of mosquito suitability conditions based on the number of water bodies and the volume of vegetation per neighborhood for the years 2016 and 2012, respectively, with the following classes: no vegetation or hydrography; scarce vegetation and hydrography; and high vegetation and hydrography. Our analysis utilized existing Geographic Information System (GIS) maps of water body boundaries and vegetation communities ${ }^{14}$, which were validated and refined for the current study.

All of the indicators utilized in this analysis were imported into a GIS environment for analysis. We partitioned continuous variables into classes defined using Jenks' natural breaks. This approach divides frequency classes into natural groups that define the quantity and intervals of data that the classes will contain for a given variable. In this manner, occurrences are divided into frequency classes whose limits are defined based on large differences among their values ${ }^{18}$.

Next, we tallied the API for each district, defined as the number of cases of malaria for which the district in question was listed as the probable site of infection in the case report form (CRF), divided by the population of the district. In addition, an adapted API was calculated, defined as the number of cases of malaria for which the district in question was the residence of the infected person, according to the CRF, again divided 
by the population. After calculating the API for each district, we calculate the mean API for each class of the two typologies. We tested whether the mean API was different in the central area of the city, in consolidated suburbs, suburbs in expansion, and middle-class areas in expansion using Analysis of Variance (ANOVA). In a similar manner, we used ANOVA to assess whether the mean API was significantly different in districts with no vegetation and water bodies, scarce water bodies and vegetation, and elevated levels of vegetation and water bodies. Additionally, we calculated the linear correlation between the API of each neighborhood and the volume of vegetation and the number of waterbodies.

The construction of indicators requires an underlying conceptual model of the processes that generate the phenomena being examined ${ }^{19}$. To develop such a model, we carried out fieldwork in Porto Velho with the goals of observing the effects of major energy projects and validating our initial set of social and environmental indicators.

\section{Results}

From 2003-2018, 204,458 cases of urban malaria were notified in Porto Velho, with an annual mean of 11,359 cases. The API in the city decreased over the study, although it is still greater than the mean of the state of Rondônia. Exceptions to the overall pattern of decreasing API include 2007, 2010, 2012, and more recently, 2017 and 2018 , when the API increased by $47 \%, 6 \%$, $2 \%, 54 \%$, and $20 \%$ over the previous year (Figure 1). 2017 was the first year in which the API was higher in urban than in rural areas.

Figure 2 shows the mean API by district in the urban center of Porto Velho. These data reveal that the index of malaria was highest in periurban areas. From 2005-2007, of the 69 districts, 13 had an API of greater than 50 malaria cases per 100,000 inhabitants. The spatial pattern was similar in 2008-2010 and 2011-2013. However, despite the general declining trend in API, in 2011-2013 the API increased in 13 districts located in the southern and eastern sectors of the city. The API in 2014-16 was the lowest in history. During this period, the sole district to report an increase was the central area Porto Velho.

Figure 3 shows Typology I: Functional Characteristics of Urban Spaces. As noted above, this typology divided the urban area of Porto Velho into: central area (25\%), consolidated suburb
(25\%), suburb in expansion (25\%), and middle class area in expansion $(25 \%)$. The results indicated that neighborhoods in a given class tended to be spatially contiguous with one another.

Chart 1 (A) shows the API according to the Functional Characteristics of Urban Spaces typology. There was a declining trend of API in all classes of the typology throughout the historical series. The difference in API among classes was significant (ANOVA: $\mathrm{F}=18.33, \mathrm{p}=3.48 \times 10^{-5}$ ) and was driven by the fact that API in the central area was lower than in the other classes. However, the API was no different in the consolidated suburb, suburb in expansion, and middle-class area in expansion, as the confidence intervals of these classes overlap (Figure 4). 2014-2016 can be considered an exception to this pattern, as the central area had an IPA value of 3.9 cases per 100,000 inhabitants, slightly higher than the suburb in expansion class for the period (3.5 per 100,000 inhabitants). Also, during this same period, the incidence of malaria in the middle-class area in expansion was twice as high as the central area.

We also classified the neighborhoods of Porto Velho into three classes of mosquito suitability. This classification was based upon vegetation and hydrology. As noted above, neighborhoods in a given class tended to be clustered together in close spatial proximity to one another. Neighborhoods classified as "elevated vegetation and water bodies" were mostly located in the periurban region of the city. An exception to this pattern was that there were a few "elevated vegetation and water bodies" neighborhoods in the western sector of the city. Most of the other western neighborhoods were classified as "scarce vegetation and water bodies".

Chart 1 (B) shows the results of the API for each category of mosquito suitability. As noted above, there was a decreasing trend of API throughout the historical series. The highest API values were encountered in neighborhoods with "elevated vegetation and water bodies". An exception to this pattern was 2014-2016 when the API was highest in "scarce vegetation and water bodies" neighborhoods. There was a significant difference in API among neighborhoods in different classes of mosquito suitability (ANOVA: $\left.\mathrm{F}=19.98, \mathrm{p}=1.64 \times 10^{-5}\right)$. The API was highest in neighborhoods classified as high vegetation and hydrography (Figure 4). There was a significant correlation between vegetation levels and the API at the neighborhood scale $(\mathrm{r}=0.45, \mathrm{p}=1.1 \times 10-4)$. The number of waterways per neighborhood was also correlated with the API, though this relationship was weaker $(r=0.27, p=0.02)$. 


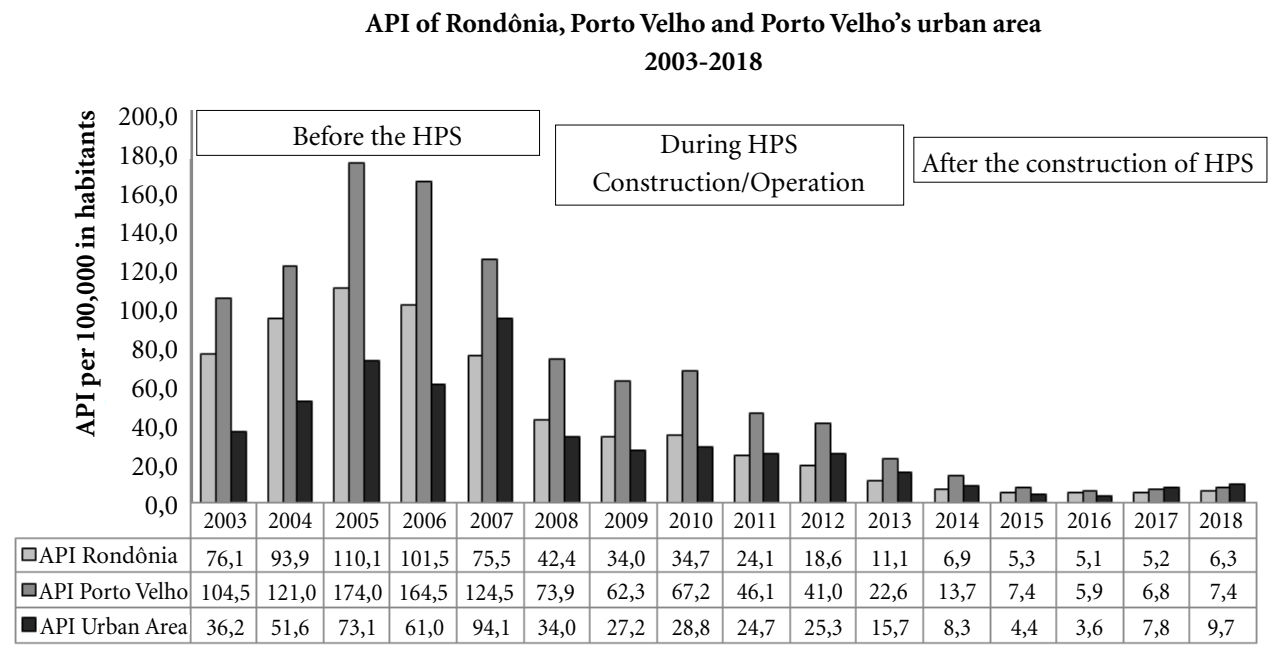

Figure 1. Time series of the annual parasite index for the state of Rondônia, the entire municipality of Porto Velho - that includes urban and rural areas - and the urban center of Porto Velho.

Source: SIVEP-Malária and IBGE. Elaborated by the authors.

\section{Discussion}

The API decreased over the study, both in Porto Velho and Rondônia as a whole. It is noteworthy that the dynamics of malaria epidemics were different in the urban and rural areas of the municipality. Malaria risk was lower in urban and periurban areas than in rural areas due to better housing, socio-economic conditions, vector control, and fewer mosquito breeding sites ${ }^{7}$. Angelo ${ }^{20}$ showed that the occurrence of malaria infection in 2006 was five times higher in rural areas. However, in recent years, the API has increased in urban areas. The increase was particularly striking from 2010 to 2012, but also quite pronounced in 2017 and 2018.

When we analyzed the spatial pattern of malaria cases in Porto Velho, the API was highest in suburban neighborhoods distant from the city central area. This finding is supported by the literature on the ecological niche of the mosquito, which grows better in clean, clear water that is either fully exposed to the sun or partially shaded by floating vegetation. This pattern has been observed in other Amazonian cities such as Manaus in which the occurrence of malaria has been linked to factors such as urban expansion (and accompanying deforestation) along with anthropogenic activities that alter the environment by creating artificial water bodies such as dams and fish farms ${ }^{6,17,20-23}$.

Since the $19^{\text {th }}$ Century, large infrastructure projects have influenced land use and urban zoning in the Amazon. Over the past 20 years, Brazil's Growth Acceleration Program (Portuguese acronym: PAC) brought to Porto Velho the implementation of major social, urban, logistics and energy infrastructure, such as the Madeira River $\mathrm{HPSs}^{20}$. In particular, the Santo Antônio and Jirau HPSs brought about considerable changes in land use and urban growth in nearby municipalities. These included increased migration, deforestation, demand for goods and services, and investment in urban infrastructure.

In this context, one can identify three distinct phases of the migration of workers employed by these hydroelectric projects: 1) planning and design, 2) construction of infrastructure, and 3) reservoir filling and operation. The first is characterized by the recruitment of skilled labor and multidisciplinary technical staff for the development of engineering and environmental studies. The second had the most significant impact on the region, due to workforce mobilization for the implementation phase of the projects. The last phase is characterized by a declining demand for temporary labor, producing a high unemployment rate, especially among unskilled workers. 


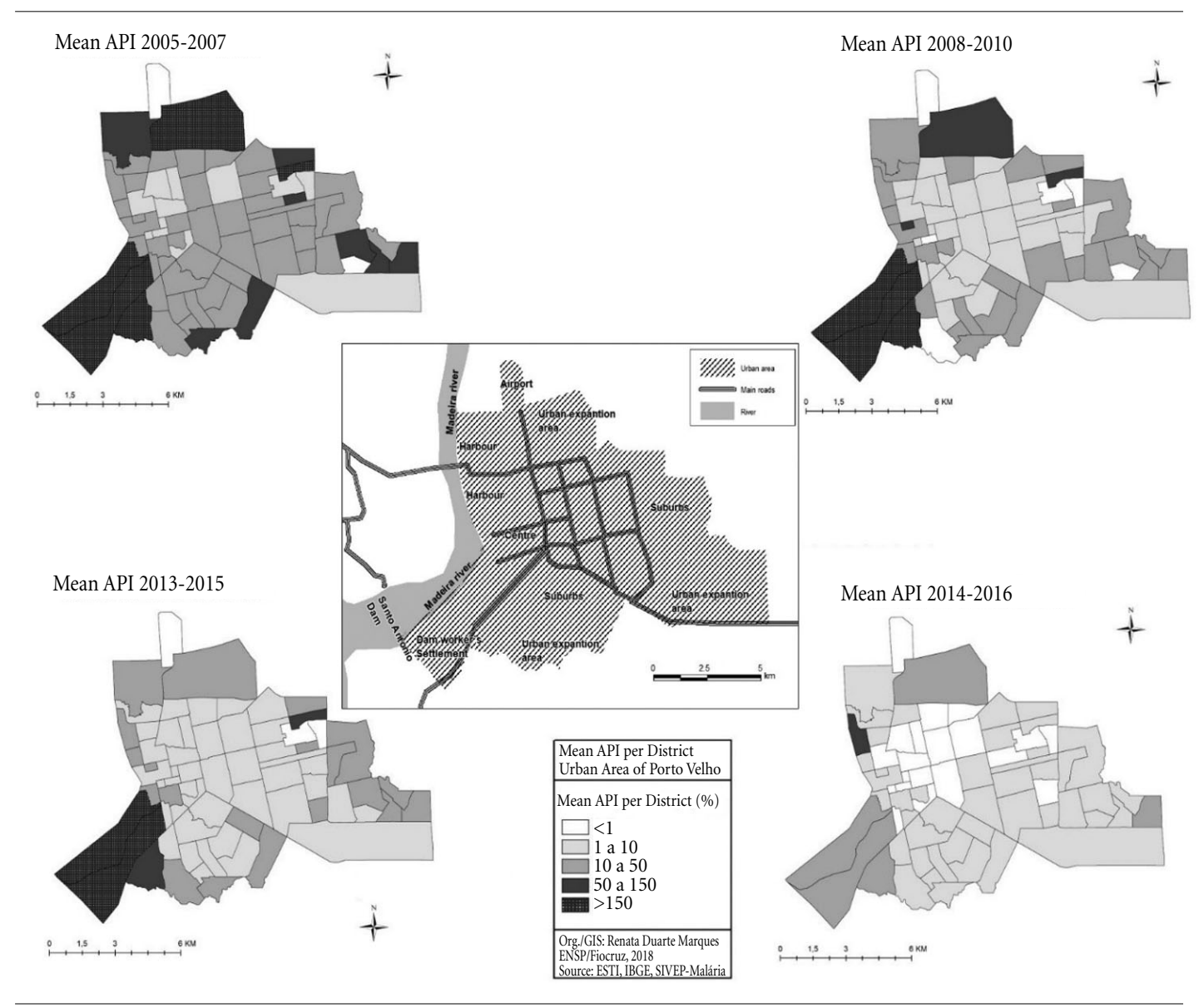

Figure 2. Mean annual parasite index for the urban center of Porto Velho (It is assumed that individuals were infected at home).

Sources: ESRI, IBGE, SIVEP-Malária. Elaborated by the authors.

By the third phase, only a small contingent of workers remained for the maintenance and operation of the hydroelectric power plants ${ }^{24}$. The high unemployment phase began in Porto Velho in 2014 with the completion of the Madeira River HPSs. In addition to the increased unemployment rate, land and housing prices declined due to reduced demand as many of the workers had already left emigrated ${ }^{25}$.

The National Household Survey (Portuguese acronym: PNAD) provides evidence that there has been an increase in migration in recent years. According to the 2010 PNAD, almost $90 \%$ of Porto Velho's residents had lived continuously in the city for less than 10 years during the period from 2000 to 2010, which contributed to the expansion of the urban area of the municipality ${ }^{10}$. Although some of these immigrants may have left Porto Velho, many of them ultimately remained in the city even after the construction of the Madeira Hydroelectric Complex and the accompanying job creation came to an end. These immigrants settled in various parts of the city depending upon their income and employment situation. Ultimately the vast majority of the immigrants moved into areas of urban expansion.

The increased API in urban areas may be associated with the production of urban space that accompanied the construction of HPSs on the Madeira River and the plants' social and geographic impacts ${ }^{10,12,14}$. In assessing the legacy of the Jirau and Santo Antônio HPSs, it is patent that the projects strengthened Porto Velho's status as a regional economic hub.

During our fieldwork in Porto Velho, we gained further insight into spatial pattern of malaria in the city. The low API in the southern part of the city appears to be linked to zoning and economic conditions, as this area consists primarily of newly-constructed condominiums inhabited 

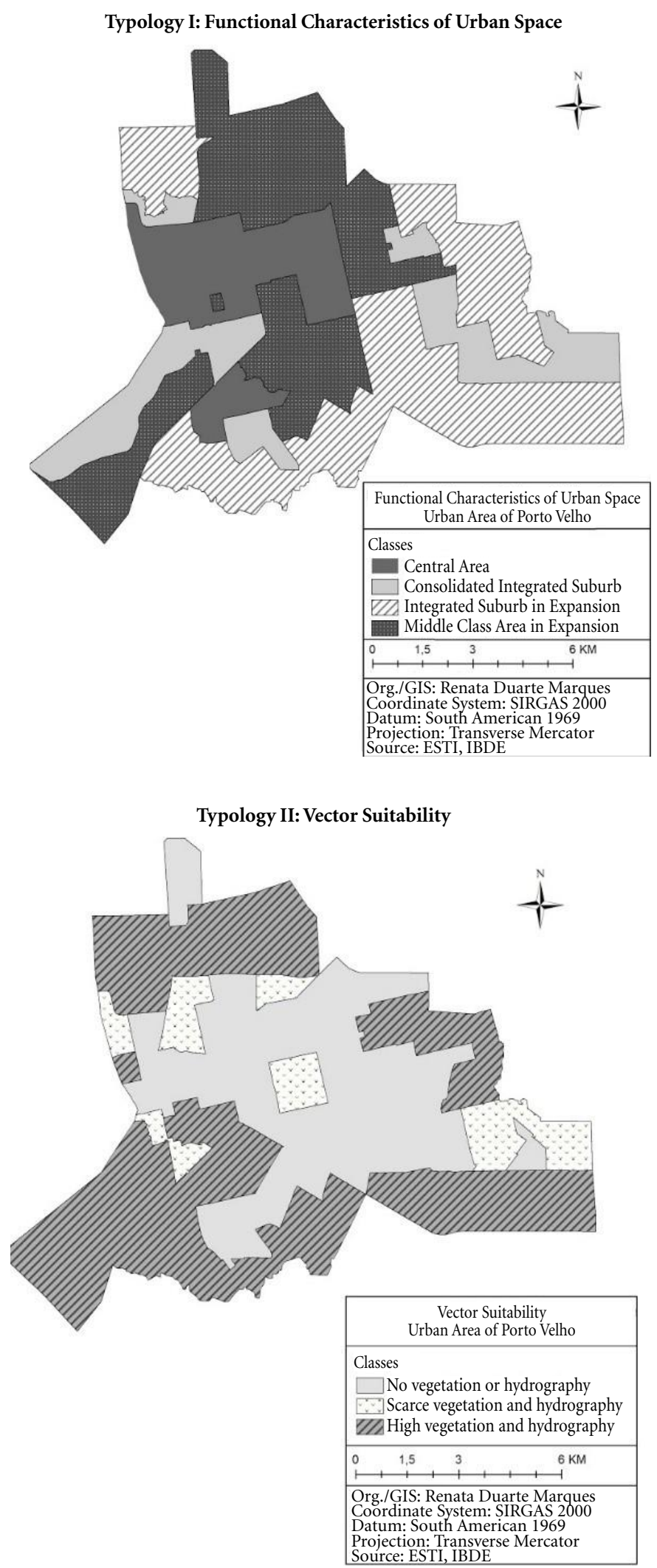

Figure 3. Typologies I and II.

Source: ESRI, IBGE. 
Chart 1. Mean API annual parasite index adapted based on Typology I: (A) Urban Space Functions Functional Features of Urban Space and (B) Mean API annual parasite index adapted based on Typology II: Vector Suitability.

\begin{tabular}{|c|c|c|c|c|}
\hline \multicolumn{5}{|c|}{ (A) } \\
\hline Classes (\%) & $\begin{array}{c}\text { API } \\
2005-2007\end{array}$ & $\begin{array}{c}\text { API } \\
2008-2010\end{array}$ & $\begin{array}{c}\text { API } \\
2011-2013\end{array}$ & $\begin{array}{c}\text { API } \\
2014-2016\end{array}$ \\
\hline Downtown & 13.7 & 7.2 & 4.3 & 3.9 \\
\hline Consolidated Integrated Suburb & 32.9 & 17.2 & 15.6 & 2.6 \\
\hline Expanding Integrated Suburb in Expansion & 47.5 & 21.7 & 16.8 & 3.5 \\
\hline Middle-Class Expansion Area in Expansion & 25.6 & 12 & 7.6 & 1.8 \\
\hline \multicolumn{5}{|c|}{ (B) } \\
\hline Classes (\%) & $\begin{array}{c}\text { API } \\
2005-2007\end{array}$ & $\begin{array}{c}\text { API } \\
2008-2010\end{array}$ & $\begin{array}{c}\text { API } \\
2011-2013\end{array}$ & $\begin{array}{c}\text { API } \\
2014-2016\end{array}$ \\
\hline No vegetation or hydrography & 19.3 & 8.6 & 6 & 1.5 \\
\hline Scarce vegetation and scarce hydrography & 27.3 & 15.5 & 13.5 & 6.5 \\
\hline High vegetation and high hydrography & 51.4 & 25.5 & 19.8 & 3.9 \\
\hline
\end{tabular}

Source: SIVEP-Malária and IBGE. Elaborated by the authors.

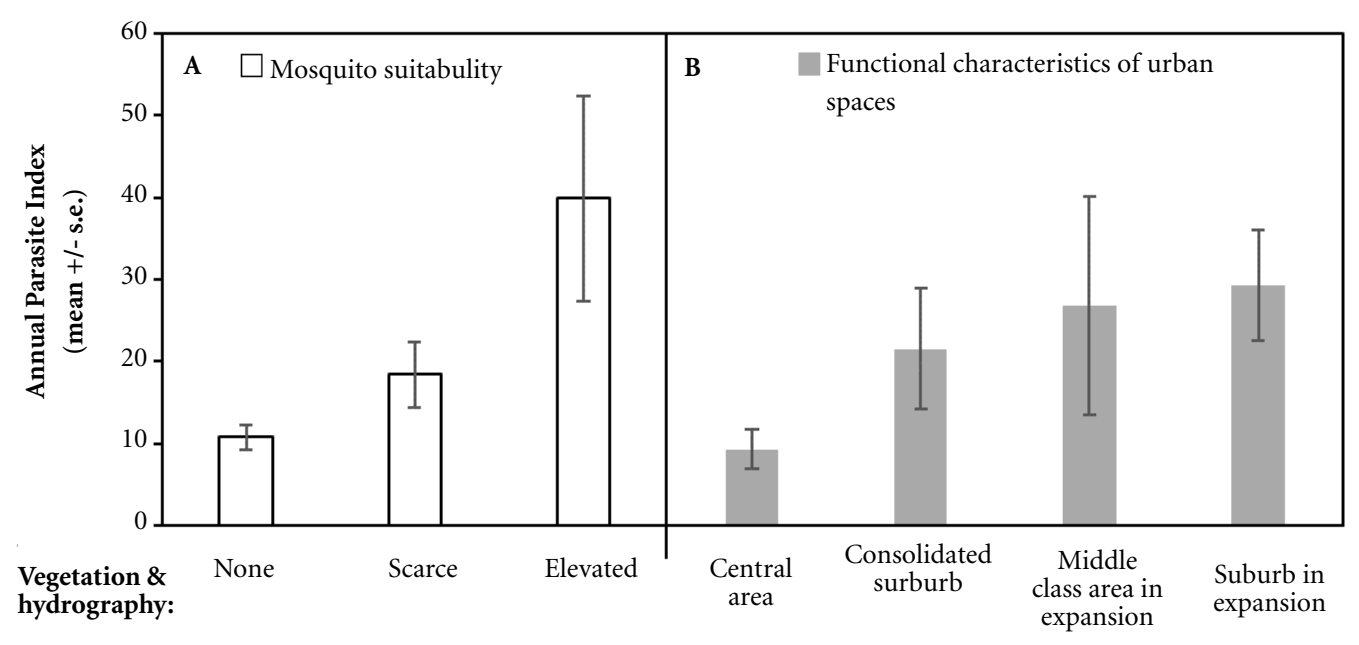

Figure 4. Annual parasite index of the districts of Porto Velho. (A) Index of suitability for mosquito vectors, and (B) Functional characteristics of urban spaces. Bars $=$ mean $+/$ - standard error. Analysis of variance $(\mathrm{p}<0.001)$.

Sources: IBGE and SIVEP-Malaria. Elaborated by the authors.

by the upper middle class. On the other hand, neighborhoods in the northern and eastern parts of the city were the site government-subsidized lower middle-class housing and informal settlements lacking sanitation infrastructure.

An important dimension of malaria epidemics in urban areas is that cases are typically concentrated near mosquito infestations, which often begin in informal settlements. Rapid population growth in the absence of urban zoning may foster proliferation of breeding sites. However, as growth slows and city planners implement zoning restrictions, malaria cases gradually decline ${ }^{22}$.

The urban area of Porto Velho exhibits the typical pattern of malaria cases by age and sex, with the highest prevalence in 20-39-year-old males. The number of cases in this demographic may be due to their mobility, as individuals in this group typically live in one neighborhood but work in another. As a result, they may travel between rural and urban or periurban areas, which provides opportunities for malaria transmission ${ }^{7,9,19,20,26}$. 
The occurrence of malaria transmission in the urban area of Porto Velho remained high until 2007, when the API declined by $64 \%$. This decline was due to the widespread adoption of artemisinin-based therapy in late 2006 based on the WHO recommendations. Similar declines were observed throughout the Amazon in this period ${ }^{6}$.

We calculated an adapted API that assumed the individual was infected at home as well as the standard index. The results indicated that the adapted index was lower than the standard index. A mechanism that could explain this pattern is that many individuals contracted malaria outside the neighborhood where they lived. This pattern would underscore the importance of commuting for explaining the dynamics malaria. A salient example is construction workers at the Madeira River hydroelectric complex, who often lived in the urban center of Porto Velho or surrounding neighborhoods, and contracted malaria at their job site en, 10,28 .

Construction of the Madeira hydroelectric complex peaked between 2011 and 2013. It is undeniable that the project brought about with vast changes in the urban infrastructure of Porto Velho. We have argued that the construction project was associated with increased API in urban areas. Hence, one might expect the API to have reached its peak in the period of 2011-2013. In fact, although the index increased in some neighborhoods during this period, the overall trend was a decline. This apparent contradiction can be explained by the fact that the construction company implemented a malaria eradication program during this period to comply with its operating license $\mathrm{e}^{29}$. Furthermore, as noted above, 2011-2013 followed the rollout period artemisinin-based therapy in the region.

It is worth noting that high population growth is not inherently linked to increased API. For example, if population growth were decoupled from social vulnerability or greater suitability for Anopheles mosquitoes, the API might not increase. In Porto Velho, neighborhoods with high population growth as well as a high API were primarily located in the suburbs and vegetation and hydrographic features suitable for mosquito breeding sites.

In the mid-2000s, the Madeira River hydroelectric complex and the Growth Acceleration Program triggered a real estate boom in Porto Velho that resulted in a process of urban verticalization. The city also experienced significant horizontal expansion during this period. Much of the urban area consists of buildings with a maximum of three floors, as we observed during fieldwork. The horizontal growth of the city also led to new construction in areas that had been vacant, due to the demand caused by the increased population of the city. Figure 4 shows that, in addition to expansion of the northern, eastern, and southern sectors of the city, there was also significant growth in the southeast. Despite being expanding areas, these districts did not have high indices of parasitism, possibly because they are zoned commercial rather than residential, or have better infrastructure. According to our classification, such areas would be categorized as consolidated urban space and not considered suitable for malaria.

The construction of hydroelectric power plants produced high economic and population growth in the municipality of Porto Velho. Various indicators of urban infrastructure are higher in Porto Velho than in other municipalities in Rondônia. Nevertheless, Porto Velho's indicators are still too low due to the considerable inequality of housing and infrastructure within the city ${ }^{30,31}$. In informal settlements, walls of homes are either absent or incomplete, which facilitates human contact with the malaria vector - the Anopheles mosquito - and hinders the application of insecticides.

Another socio-spatial dynamic observed in the urban area of Porto Velho is the displacement of informal settlements from the central area of the city to the suburbs north and east of the central area. The city has made progress regarding land tenure regularization. However, this process remains controversial due to the city's tradition of prohibiting irregular occupations, and neglecting to provide municipal services and infrastructure in economically-disadvantaged neighborhoods $^{32}$.

The expansion of Porto Velho's urban center has been limited by physical barriers - such as the presence of streams - as well as for institutional reasons - such as the presence of the airport in the northern area and a large military area. To the south, growth is limited by Highway BR-364, which has caused the city to expand eastward into higher and flatter land suitable for urbanization. However, eastward growth has followed a leapfrog pattern leaving considerable gaps along the way. This process of production of urban space has hindered the provision of infrastructure and social services to populations living in the gaps ${ }^{15,27,33}$.

The adapted API was highest values in the "suburb in expansion" class for much of the 
study period. This pattern may be because this region is the site of several urban gap areas. The population of these gaps consists primarily of the workforce that migrated in pursuit of employment at the HPSs.

Our fieldwork revealed that many dam workers emigrated from Porto Velho on completion of construction. Most of the individuals who remained in the city settled in the central area, which has several hotels and guesthouses serving this clientele. Post-construction migration to the central area may have increased the API in this part of the city. Other neighborhoods did not maintain the same rate of population growth and experienced an emptying out as dam workers returned to their hometowns or sought employment elsewhere.

According to our malaria suitability typology, the adapted index of parasitism was highest in districts with elevated vegetation and hydrography, except for the 2014-2016, when the index was highest in districts with low vegetation and hydrography.

Of course, the presence of vegetation and hydrography are not necessary and sufficient conditions of the malaria transmission cycle. As noted by Rodrigues et al. ${ }^{34}$ and confirmed during our fieldwork, many of the streams near the central area have been diverted into artificial waterways that are unsuitable for Anopheles reproduction due to pollution, turbidity, and the velocity of the current. While municipal ordinances prohibit building homes near such waterways, these laws are seldom enforced.

On the other hand, the API considered on the suitability typologies uses the water bodies and the volume vegetation per neighborhood for the years 2016 and 2012, respectively. Thus, the periods that are closer to these years have more precise information. Besides that, the indicators are an estimation of the reality, since the territory is highly dynamic.

In periurban areas of the city that are located near the Madeira River, the municipal government constructed wetlands for wastewater treatment $^{35}$. As streams in these areas are recharged by regular flooding of the Madeira, they are less turbid and polluted than the canals downtown. These hydrographic characteristics could make peri-urban streams more suitable as Anopheles breeding sites.

Understanding these relationships and geographic features of the urban landscape can facilitate the implementation of public health policies $^{36}$. The identification of priority health problems in a given population, as well as their spatial distribution across the territory within their historical and geographical context, is essential for assessing trends in syndromic surveillance data ${ }^{37}$. Porto Velho and the Amazon region have experienced recent urbanization, which, among other factors, influence the dynamics of malaria in the region, especially in populous regional economic hubs. We found that the API with highest in peri-urban neighborhoods. However, this study revealed that the malaria transmission cycle in Porto Velho is a complex process, reflecting the region's history of land use and the organization of urban spaces.

\section{Conclusions}

In recent decades, malaria epidemics in Porto Velho have been strongly influenced by changing social and geographic processes in the Amazon. Thus, the analysis of malaria transmission should take into consideration the social, economic, and ecological changes that have occurred in the city. These include shifts in land use/land cover, urban sprawl, population growth, economic diversification, large infrastructure projects including the Santo Antonio and Jirau HPSs, and most importantly, increased connectivity due to the expansion of road and river transportation networks.

Our findings demonstrate the utility of spatial modeling for planning disease surveillance and identifying geographic locations and features of the landscape that are associated with the occurrence of malaria epidemics.

Although our study does not explain all the intricacies of the malaria transmission cycle, we believe that a significant contribution of this work has been to demonstrate the extent to which the process of production of urban space in Porto Velho has created social and environmental conditions that have enabled this cycle to persist by contributing to favorable conditions for malaria infection in particular neighborhoods. We believe that future epidemiological surveillance should be knowledge-based and advance beyond identifying environmental variables that are merely correlated with disease incidence. Instead, such surveillance should analyze the social and historical context of endemic areas, while keeping in mind the importance of geographic connectivity for the persistence of infectious diseases. 


\section{Collaborations}

RD Marques designed, conceived and developed the study by analyzing and interpreting the data and writing the paper. C Barcellos and JR Angelo participated in the design, orientation, critical review of the interpretation and analysis of data, and drafting of the paper. AA Lima participated in the territory study, interpretation, and the intellectual content analysis of the paper. $\mathrm{T}$ Fuller collaborated with the statistics analysis, critic review, data and intellectual content analysis, approving the last version of the paper.

\section{Acknowledgments}

The authors thank the Coordenação de Aperfeiçoamento de Pessoal de Nível Superior (CAPES) and the Escola Nacional de Saúde Pública Sérgio Arouca for supporting this study.

\section{Funding}

The research was funded by PROEX-CAPES and the Escola Nacional de Saúde Pública Postgraduate Program (ENSP/Fiocruz).

\section{References}

1. Tauil P, Deane L, Sabroza P, Ribeiro C. A malária no Brasil. Cad Saude Publica 1985; 1(1):71-111.

2. Becker BK. Amazônia. São Paulo: Editora Ática; 1990.

3. Barata RB. Malária e seu controle. São Paulo: Hucitec; 1998.

4. Brasil. Ministério da Saúde (MS). Secretaria de Vigilância em Saúde. Departamento de Vigilância Epidemiológica. Doenças infecciosas e parasitárias: guia de bolso. 6a ed. rev. Brasília: MS; 2005.

5. Brasil. Ministério da Saúde (MS). Doenças negligenciadas: estratégias do Ministério da Saúde. Rev Saude Publica 2010; 44(1):200-202.

6. Brasil. Ministério da Saúde (MS). Secretaria de Vigilância em Saúde. Situação epidemiológica da malária no Brasil, 2000 a 2011. Bol Epidemiol 2013; 44(1):1.

7. Mathanga DP, Tembo AK, Mzilahowa T, Bauleni A, Mtimaukenena K, Taylor TE, Valim C, Walker ED, Wilson ML. Patterns and determinants of malaria risk in urban and peri-urban areas of Blantyre, Malawi. Malar J 2016; 15:590.

8. Recht J, Siqueira AM, Monteiro WM. Malaria in Brazil, Colombia, Peru and Venezuela: current challenges in malaria control and elimination. Malar J 2017; 16:273.

9. Wilson ML, Krogstad DJ, Arinaitwe E, Arevalo-Herrera M, Chery L, Ferreira UM, Ndiaye D, Mathanga DP, Eapen A. Urban Malaria: Understanding its Epidemiology, Ecology, and Transmission across Seven Diverse ICEMR Network Sites. Am J Trop Med Hyg 2015; 93(Supl. 3):110-123.

10. Angelo JR, Katsuragawa TH, Sabroza PC, Carvalho LAS, Silva LHP, Nobre CA. The role of spatial mobility in malaria transmission in the Brazilian Amazon: The case of Porto Velho municipality, Rondônia, Brazil (2010-2012). PLoS One 2017; 12(2):e0172330.

11. Katsuragawa TH, Gil LHS, Tada MS, Silva LHP. Endemias e epidemias na Amazônia: malária e doenças emergentes em áreas ribeirinhas do Rio Madeira. Um caso de escola. Estud Av 2008; 22(64):111-141.

12. Barcellos C, Xavier DR, Bulcão JAS, Silva HVO, Luigi G, Silva DS, Moura FH, La Rovere EL. Health risk assessment associated with the implementation of the Madeira hydroelectric complex, Brazilian amazon. Ambient Soc 2018; 21:e00191.

13. Carlos AF. A condição espacial. São Paulo: Ed. Contexto; 2011.

14. Silva HRO, Guimarães SCP, Oliveira LB. O uso do geoprocessamento na espacialização e avaliação das Áreas de Preservação Permanente: Cidade de Porto Velho-RO. Confins 2017; 30.

15. Porto Velho. Lei Complementar no 311 , de 30 de junho de 2008. Dispõe sobre o Plano Diretor do município de Porto Velho e dá outras providências. Diário Oficial do Município de Porto Velho; 2008.

16. Tauil PL. Condições para a transmissão da febre do vírus chikungunya. Epidemiol Serv Saude 2014; 23(4):773-774.

17. Consoli RAGB, Oliveira RL. Principais mosquitos de importância sanitária no Brasil. Rio de Janeiro: Editora Fiocruz; 1994.

18. Filho-Francisco LL. Distribuição espacial da violência em Campinas: Uma análise por geoprocessamento [tese]. Rio de Janeiro: Universidade Federal do Rio de Janeiro; 2004. 
19. Andreazzi MAR, Barcellos C, Hacon S. Velhos indicadores para novos problemas: a relação entre saneamento e saúde. Rev Panam Salud Publica 2007; 22(3):211-217.

20. Angelo JR. Modelagem espacial dinâmica dos determinantes sociais e ambientais da malária e simulação de cenários 2020 para município de Porto Velho - Rondônia [tese]. São José dos Campos: INPE; 2015.

21. Olano V, Carrasquilla G, Méndez F. Urban malaria transmission in Buevaventura, Colombia: entomologic aspects. Rev Panam Salud Publica 1997; 2(6):378385.

22. Barata RB. Malaria in Brazil: trends in the last ten years. Cad Saude Publica 1995; 11(1):128-136.

23. Saraiva MGG, Amorim RDS, Moura MAS, Martinez-Espinosa FE, Barbosa, MGV. Expansão urbana e distribuição espacial da malária no município de Manaus, Estado do Amazonas. Rev Soc Bras Med Trop 2009; 42(5):515-522.

24. Alves J, Thomaz Júnior A. A migração do trabalho para o complexo hidrelétrico Madeira. In: Procedings of XIII Jornada do Trabalho. Presidente Prudente: Centro de Estudos de Geografia do Trabalho; 2012.

25. Ruiz Q. Porto Velho já vive período 'pós-usinas' [Internet]. [acessado 2018 abr 25]. Disponível em: http:// economia.estadao.com.br/noticias/geral,porto-velho-ja-vive-periodo-pos-usinas, 1512059.

26. Wanderley DM, Andrade JC, Meneguetti LC, Chinelatto MJ, Dutra AP. Malária no estado de São Paulo, Brasil, 1980 a 1983. Rev Saude Publica 1985; 19:28-36.

27. Borges A. Camargo Corrêa coloca 1,2 mil funcionários de Jirau em hotéis [Internet]. 2012 [acessado 2018 abr 30]. Disponível em: http://www.valor.com.br/brasil /2603424/camargo-correa-coloca-12-mil-funcionarios-de-jirau-em-hoteis.

28. Lima AA. Análise espacial dos casos de malária no município Porto Velho no estado de Rondônia (2004 a 2014) [dissertação]. Porto Velho: Universidade Federal de Rondônia; 2016.

29. Lapouble OMM, Santelli ACFS, Muniz-Junqueira MI. Situação epidemiológica da malária na região amazônica brasileira, 2003 a 2012. Rev Panam Salud Publica 2015; 38(4):300-306.

30. Nascimento CP, Santos C, Silva M. Porto Velho: A produção do espaço urbano de Rondônia (1980/2010). Rev Geografar 2012; 7(1):20-52.
31. Goncalves KS, Siqueira ASP, Castro HA, Hacon SS. Indicador de vulnerabilidade socioambiental na Amazônia Ocidental. O caso do município de Porto Velho, Rondônia, Brasil. Cien Saude Colet 2014; 19(9):38093818.

32. Tamboril FAB, Silva RGC. A cidade de Porto Velho e a questão fundiária. In: Anais do XVIII Encontro Nacional de Geógrafos. São Luís; 2016.

33. Vilella TCS. Da borracha às turbinas - a produção do espaço de Porto Velho - RO [dissertação]. Porto Velho: Universidade Federal de Rondônia; 2008.

34. Rodrigues ERD, Holanda IBB, Carvalho DP, Bernardi JVE, Manzatto AG, Bastos WR. Distribuição espacial da qualidade da água subterrânea na área urbana da cidade de Porto Velho, Rondônia. Scientia Amazonia 2014; 3(3):97-105.

35. Angelo JR, Katsuragawa TH, Lima AA, Pereira-da-Silva LH, Nobre CA. Expansão urbana e ocorrência da malária na área urbana de Porto Velho (RO). In: XIII Reunião Nacional de Malária. Manaus; 2013.

36. Faria RM, Bortolozzi A. Espaço, Território e Saúde: Contribuições de Milton Santos para o Tema da Geografia da Saúde no Brasil. RAEGA 2009; 17:31-41.

37. Castellanos PL. Análisis de la situación de salud de poblaciones. In: Martínez-Navarro F, organizador. Vigilancia epidemiológica. España: McGraw Hill-Interamericana; 2004. p. 193-213.

Article submitted 20/11/2019

Approved 23/07/2020

Final version submitted 25/07/2020

Chief editors: Romeu Gomes, Antônio Augusto Moura da Silva 